\section{Pugio Bruti}

\section{Petterson (D) and Rosengren (A). Latinitium 2018. Pp. $104 \$ 15.99$}

\section{Charlotte Goddard}

Head of Classics, Ampleforth College

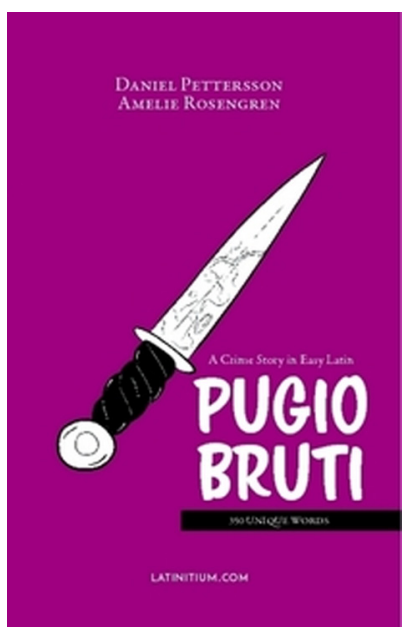

Pugio Bruti is a short Latin story (under 10,000 words, of which only 350 are unique), a mystery and a whodunnit, involving a quest through Rome in search of the thief of a dagger (the very dagger with which Brutus stabbed Caesar), its recovery and its secret message. It is a story of adventure and danger, and there is plenty of humour too. The cast of well-defined characters includes a lecherous innkeeper and a feisty young heroine. There are some clever plot twists at the end. Engaging line drawings and a complete glossary make this an attractive book; macra are marked, which can be helpful, though some of my pilot student readers were surprised, and initially unnerved, to see capitals at the start of sentences.

A familiar tool in modern language education, the novella is a relative stranger to the Latin classroom, at least in British schools. Yet literature and reading comprehension are key requirements in the assessment of Latin at GCSE and A Level, accounting for a higher proportion of marks in these qualifications than they do in modern languages. Reading courses are popular for beginners in Latin, but progression from the text book to original texts, even simplified ones, can be the greatest obstacle faced by Latin students. This hurdle is often faced at the start of A Level courses.

Recent reform of A Level qualifications has unwittingly added a further obstacle. The AS examination is no longer an integral part of the A Level and as a result many schools and colleges expect students to start the sixth form following four A Level courses, from which they opt out of one during the first year. Such an approach delivers the requirements of university entrance but encourages students to identify and deselect the subject they find the least appealing and in which they are least confident, presenting a challenge for heads of department especially in niche subjects such as Latin. My own experience last year of losing most of my Year 12 Latin class by the end of the first term prompted me to rethink my approach and to seek some attractive material which would be enjoyable to read, encourage continued study, foster confidence and fluency, and help launch intermediate readers into reading original Latin. When I first read Pugio Bruti, and enjoyed it at a single sitting, I felt that this might be just what I was looking for. I am therefore trialing it with my current Year 12 students, who have about five years of Latin behind them and have recently done well at GCSE.
Co-author Daniel Petterson writes in the preface that 'Pugio Bruti is intended to be a stepping stone for students at the outset of their journey towards the ultimate goal of reading Latin from the classical period and beyond'. He does not specify how close the reader should be to the outset of their journey. A Level students are, of course, some way along it. But Pugio Bruti would be a struggle for an absolute or even a near beginner: all six tenses are used, the passive voice, a good sprinkling of deponent verbs, ablative absolutes, gerundives and a handful of constructions using the subjunctive, including frequent instances of the present subjunctive, which is not required at GCSE. There is, however, almost no indirect statement (most of the speech is direct). Some of the colloquial idioms (based on Plautus and Petronius, authors not usually read in school), which may in fact be relatively palatable for a beginner, initially troubled my student readers.

Naturally, a reader need not have been taught all the constructions before being able to understand them in context; this is a fundamental principle of reading-based approaches to learning Latin. However, unless a certain proportion of the language can be intuited, reading the story can either become an exercise in guesswork or a set of problems to be dealt with. The former opens the door to errors and confusion; the latter means slowing the pace to address each new problem as it occurs. Either way, Pugio Bruti cannot be read independently unless students have already encountered most of the accidence and syntax.

The story benefits from rapid reading. Appreciation of the fastpaced plot suffers if the pace is slowed for grammatical or literary analysis. While it is occasionally necessary to pause over a sentence to unlock its structure or to correct an egregious error, it is better to devour quite large sections (say, a chapter) at a time without stopping, to maintain momentum and to reach the end (although it is short, there are 28 chapters and a prologue) in a reasonable space of time. In this the reader is helped by frequent repetition of vocabulary and by short, often very short sentences, with a far more accessible sentence structure than is found in the classical authors preferred for Latin A Level.

For my students, reading Pugio Bruti accounts for a small part of their Latin studies, supplementing the more onerous work of post-GCSE grammar, classical prose unseen translation and the study of Horace's satires. The demands of Latin A Level are such that it hard to justify devoting much curriculum time to Pugio. But while other parts of the course present them with substantial challenge, Pugio Bruti offers a measure of lighter relief which they appreciate and, if only for that reason, it justifies its share of lesson time. To date, retention on the course (one of my aims when adopting this novella) has been extremely encouraging. Students particularly enjoyed reading it in class orally as a group exercise, and some also enjoyed reading it alone and for pleasure. They find the plot entertaining, although perhaps better suited to younger students (they are 16). Most claimed that they find the Latin easy, but despite the limited lexicon, difficulty with vocabulary recognition was identified as the chief obstacle to reading it more fluently. The modern young student, even of Latin, does not tend to like using a glossary. In the light of their views, I am tempted to offer the text to younger students, if I can find any who have both the time and the levels of Latin to pick this up and read with understanding. 